Of One Blood 



\section{Of One Blood}

Abolitionism and the Origins of Racial Equality

\section{Paul Goodman}

UNIVERSITY OF CALIFORNIA PRESS

Berkeley · Los Angeles · London 
University of California Press

Berkeley and Los Angeles, California

University of California Press, Ltd.

London, England

(C) 1998 by

The Regents of the University of California

Library of Congress Cataloging-in-Publication Data

Goodman, Paul, 1934-I995.

Of One Blood: abolitionism and the origins of racial equality. / Paul Goodman.

p. $\mathrm{cm}$.

Includes bibliographic references and index

ISBN 0-520-20794-7 (cloth : alk. paper)

I. Antislavery movements-United States-

History-I9th century. 2. United States-

Race relations. 3. Afro-Americans-Civil

rights-History-I9th century. I. Title.

E449.G67 1998

973.7'II4-dc21

$97-45560$

Printed in the United States of America

$\begin{array}{lllllllll}9 & 8 & 7 & 6 & 5 & 4 & 3 & 2 & \text { I }\end{array}$

The paper used in this publication meets the minimum requirements of American National Standard for Information Sciences-Permanence of Paper for Printed Library Materials, ANSI Z39.48-1984. 


\section{For}

David and Susan Brody and

Jonathan, Pamela, and Sara 
"God hath made of one blood all nations of men for to dwell on all the face of the earth."

Acts, xviii, 26 